\title{
河川を考慮した地域地下水污染の解析
}

\author{
古市 徹 ${ }^{*} \cdot$ 林田 貴範 ${ }^{*} *$ 眞柄 泰基 ${ }^{*}$
}

\section{Numerical Analysis of Regional Groundwater Pollution Considering the Effect of River}

\author{
Tohru FURUICHI ${ }^{*}$ - Takanori HAYASHIDA ** \\ and Yasumoto MAGARA*
}

\begin{abstract}
The purpose of this study is to analyze numerically the regional groundwater pollution by TCE (Trichloroethylene) and PCE(Tetrachloroethylene) in J city, Japan. Firstly, we examine the field data measured since 1986 and display the distribution of groundwater level and concentration of TCE and PCE by a computer. Based on these data, we can guess the interrelation between the water balance of groundwater and the diffusion of pollutant in this region.

Secondly, we conduct the sensitivity analysis and the inverse estimation considering the water balance and the hydraulic conductivity distribution.

Finally, we analyze the groundwater pollution and predict the amount of mass transfer into the river from groundwater in this region, using the LOD-CFEM(Locally One Dimensional-Collocation Finite Element Method).
\end{abstract}

1.はじめに

本研究では、J市X区のトリクロロエチレン（以 下 TCEと呼ぶ)、テトラクロロエチレン（以下 PCE と呼ぶ）による污染事例を対象に現地調査及び資料 の収集整理を行い、地下水流れ場、污染状況の現況

*国立公衆衛生院、衛生工学部

**パシフィックコンサルタンッ(株)
特性を把握し、それらを踏まえた上で流れ場、濃度 場各々いついて数理モデルを構築し污染機構の解明 を試みた。モデル化においては、まず対象領域内で 降雨、河川流出量、領域内揚水量などの地下水の主 要水収支項目を考慮した流れ場のモデリングを行 い、河川流出量、領域内揚水量、透水係数に関する 感度解析、逆解析を行った。次に、LOD-CFEM (Locally One Dimensional-Collocation Finite Element Method）による濃度場の解析をして、污染プ 
リュームの搪散傾们を検討すると其に、領域内主要 河川への污染物質の流出量の预測評仙を数值シミュ レーションに基づいて試みた。

\section{2. 解析対象領域について}

図一 1 に解析対象領域を示す。領域狤辺は、周囲 をI 連峰、E山地等に囲まれた盆地で住宅地が密集 している。領域内においては Z川を含め、T川、B 川、J 川等の 4 本の通過河川があり、また $Z$ 川を境 に、領域西側に主として洪積段丘、沖積段差、氾濫 平野等が、東側に緩扇状地が認められ、地形的に複 雑な様相を呈している。また地質構成は、既往のボー リング記録により、領域全体にわたり砂碩層と粘土 層から構成される互層状態となっている。地下水の 流れについてはその流れが地形の傾斜に対応すると 仮定するならば、北東から南西方向拉よび北西から 南東方向の 2 方向の流れが尒測され、それらが領域 下流部に流下すると推察される。

\section{3. 現地調査}

領域内にて1986年から表ー 1 に示すような地下水 位、水質 (TCE, PCE 等) 調査を行った。実测地下

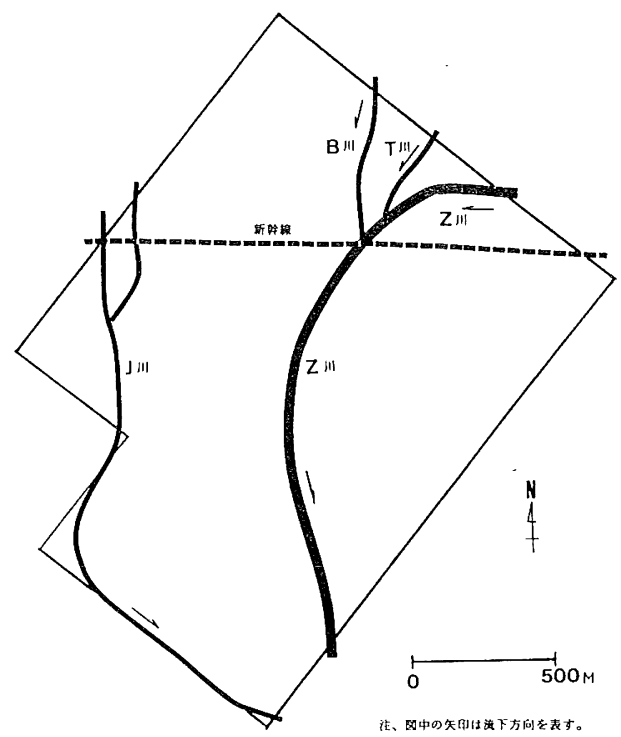

図-1 対象領域概要

Fig. 1 Investigation Region
水位分布（図-2、図-3）より、苹体的な傾向と して浅層地下水が北東から南西および北西から南東 に流れており、これらが中央部に集まり南下してい ると考えられる。また調査範囲内に招いて約 $1.0 \mathrm{~m}$ 程度の地下水位の経年的な変動が認められるが、当 市の環境月報より 2 月上够における日平均降水量小 計が1988年で35mm、1989年で435mm であること、 対象領域の地質が沖積砂砂層であることにより降雨 による一時的な地下水位上昇現象と推察され、従っ て経年的な地下水位変動を当領域内では考慮しない こととした。

表- 1 現地調查

Table 1 Field Investigation

\begin{tabular}{|c|c|c|c|c|c|c|}
\hline No. & 謂査年月 & 調查点数 & PCE & TCE & GW & 偖 考 \\
\hline 1 & 86.12 & 57 & 图 -7 & 図 -8 & * & FP \\
\hline 2 & $\begin{array}{l}87.11 \\
-88.01\end{array}$ & 11 & 図 -5 & 図 -6 & * & 水質测定 \\
\hline 3 & 88.02 & 18 & $*$ & $*$ & [四] -2 & \\
\hline 4 & 89.02 & 13 & * & * & [汶] -3 & \\
\hline
\end{tabular}

(圆形出力には NCAR.Gを使用)

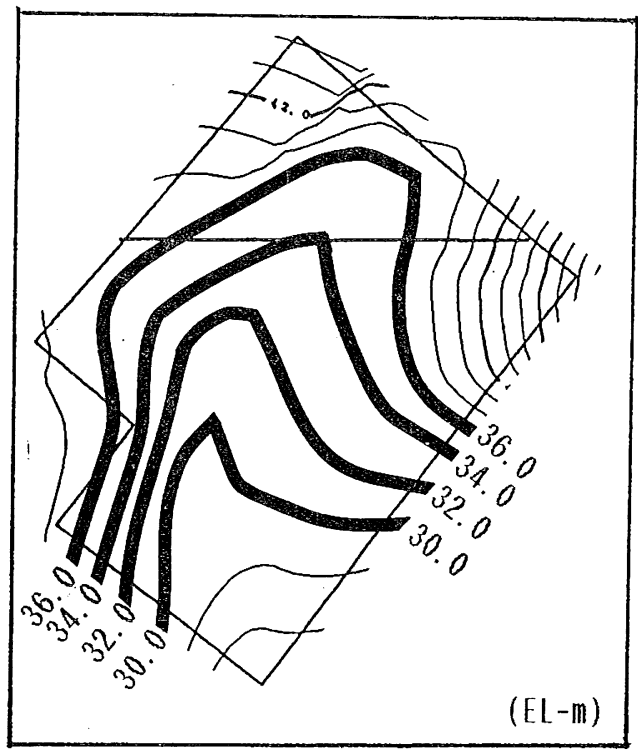

図-2 実測地下水位分布

Fig. 2 Groundwater Level Contour Map for Analysis surveyed in Feb.1988 


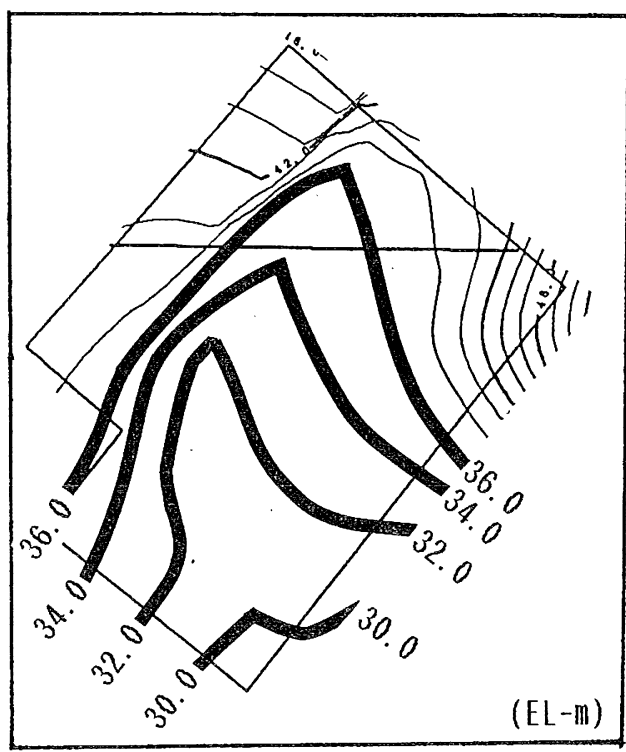

図-3 実測地下水位分布（1989.02）

Fig. 3 Groundwater Level Contour Map surveyed in Feb.1989

地下水の河川との関連でみると（表- 2 参照）、 領域上流部で $Z$ 川、T川、B川の河床高が周辺地下 水位より高く、下流部では逆に低いことが確認され た(対象河川の改修計画縦断図等)。これらの位置 関係より領域上流部で河川からの地下水かん養が ( $\mathrm{Z}$ 川上流部約 $600 \mathrm{~m} 、 \mathrm{~T} 川$ 約 $400 \mathrm{~m} 、 \mathrm{~B}$ 川約 $500 \mathrm{~m}$ )、 下流部では地下水の河川への流出が ( $Z$ 川下流部約 $700 \mathrm{~m}$ 区間) 発生しているものと推察される。また 当市が行った地下水利用実態調査表より、領域内 8 地点で地下水揚水が確認された（日平均総揚水量＝ $811 \mathrm{~m}^{3} /$ day、図 -4 参照)。

椳 -5 、図 -6 は PCE, TCE の地下水中の濃度分 布を示したものであるが、これより、領域中央部付 近に高濃度地点Aが認められ、これらを中心に北東 から南西の方向に拡がる傾向が認められる(図一 2 、 図一 3 から推測される流れと対応する)。

図ー7、図-8は PCE、TCEのフィンガープリ ント（以下 FP と呼ぶ）による測定值をもとに作成 したもので、前述の高濃度地点Aの他に、複数の高 濃度地点 $\mathrm{B} 、 \mathrm{C}$ が認められた。地下水濃度と FPに よる測定值との関係は必ずしも明確ではないが、 FPによる測定值が、少なくとも土壤及び地下水中 の污染物質の存在を示しているものとするならば、
表- 2 領域内通過河川

Table 2 Condition of River running through this Region

\begin{tabular}{|c|c|c|c|c|}
\hline \multirow[b]{2}{*}{ Z 川上流部 } & \multirow{2}{*}{\begin{tabular}{|r} 
川床高 \\
42.7
\end{tabular}} & \multicolumn{2}{|c|}{ 周辺地下水位 } & \multirow{2}{*}{ 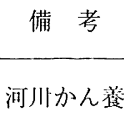 } \\
\hline & & $>$ & 33.8 & \\
\hline & 41.4 & $>$ & 34.0 & " \\
\hline & 35.7 & $>$ & 31.5 & " \\
\hline Т川 & 45.0 & $>$ & 34.7 & " \\
\hline В川 & 45.4 & $>$ & 34.7 & " \\
\hline \multirow[t]{2}{*}{ Z 川下流部 } & 29.7 & $<$ & 30.0 & 河川流出 \\
\hline & 27.0 & $<$ & 29.0 & " \\
\hline
\end{tabular}

$(\mathrm{EL}-\mathrm{m}) \quad(\mathrm{EL}-\mathrm{m})$

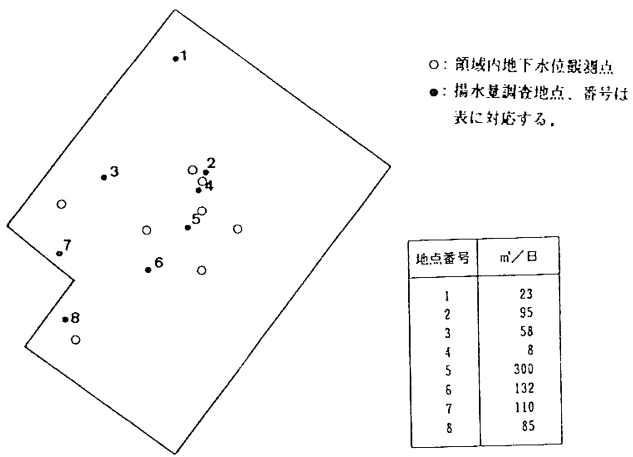

図-4 揚水量調査地点及び地下水位観測地点

Fig. 4 Location of Groundwater Pumping and Wells of surveying

当領域内において活染源が存在する可能性があると 言える。これらをもとに現地踏查により活染源の調 查を行った結果、高濃度地点 A、B 付近では污染源 と考えられる、PCE、TCEを使用している事業所の 存在が確認できた。また商濃度地点 Aについては、 その位㯰の経時的な移動も調査範网内では認められ ず、濃度場計算においては地点 A、B を連続供給を 行う污染源として、解析を行った。

4. モデル化

4.1 地下水流れ場のモデル化

(1) モデル化の仮定

上記の実測結果をもとに、浅層地下水の流れ場に 


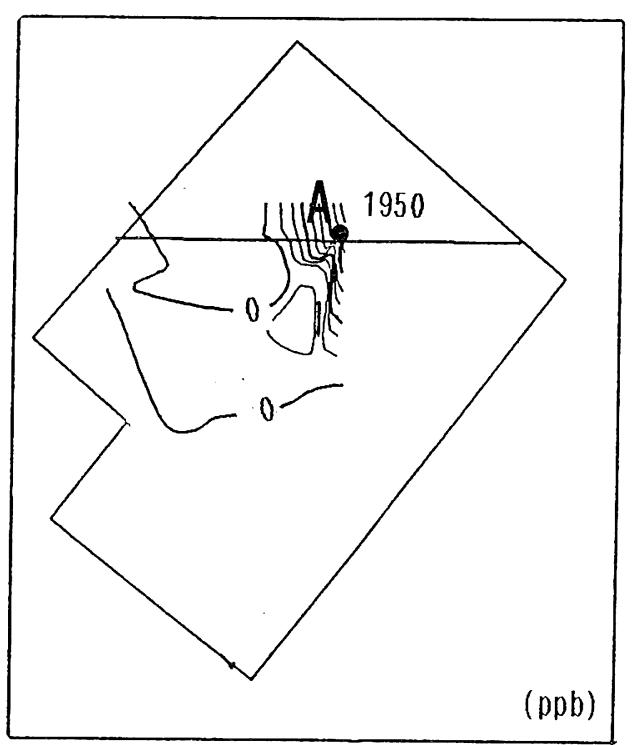

図-5 実測 PCE 濃度分布

Fig. 5 Contour Map for PCE Concentration (surveyed)

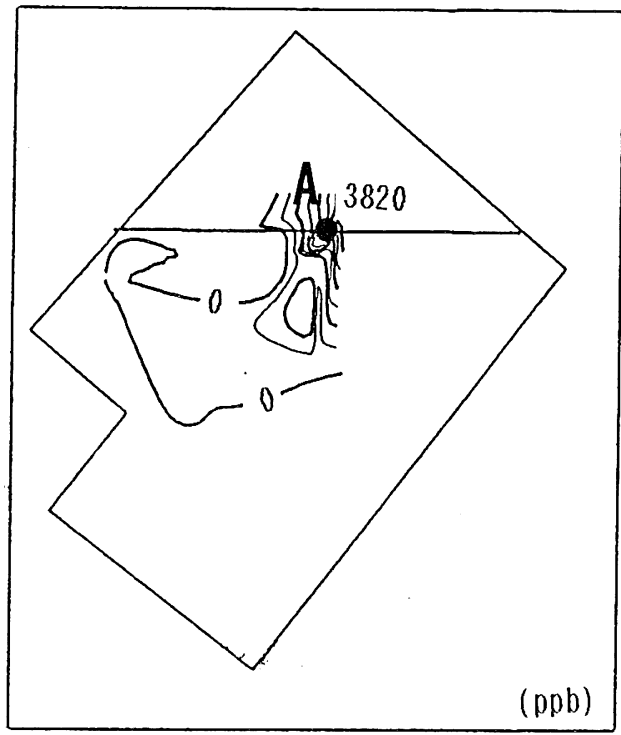

図-6 実測 TCE 濃度分布

Fig. 6 Contour Map for TCE Concentration (surveyed)

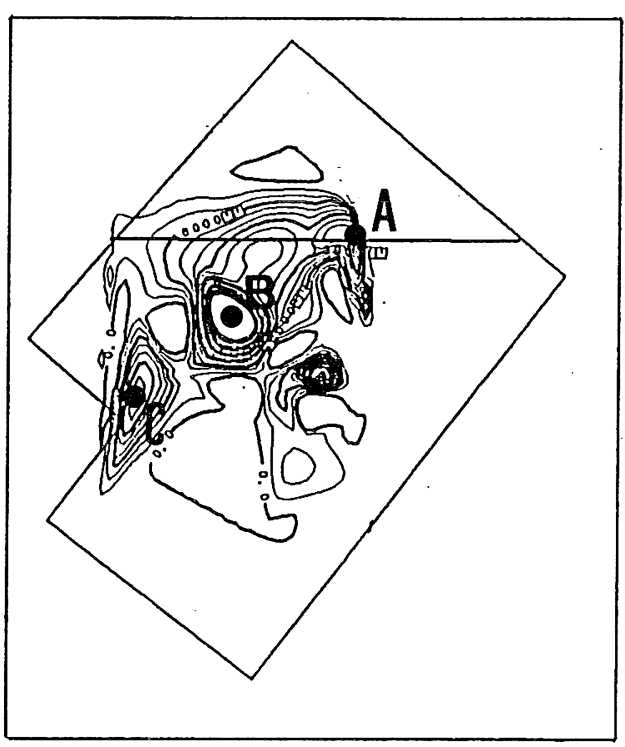

図-7 PCE 濃度分布 (FP)

Fig. 7 Contour Map for PCE Concentration (surveyed, using FP)

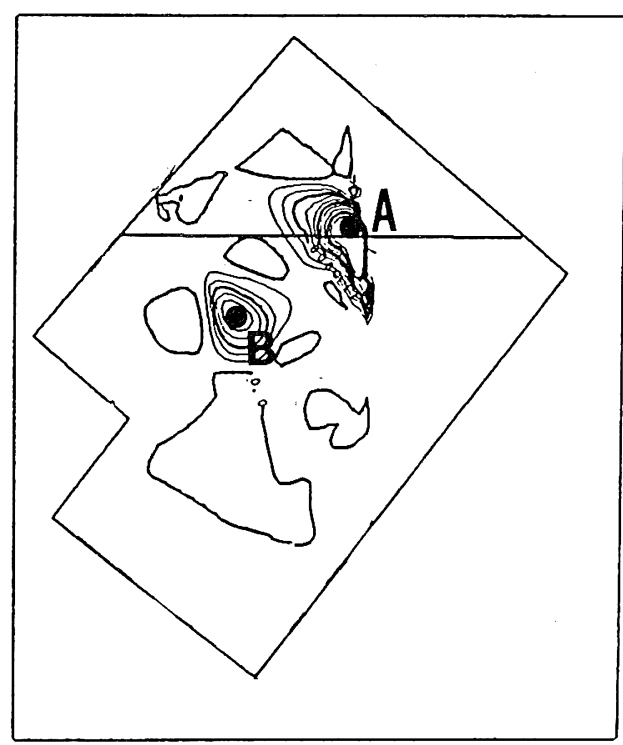

図-8 TCE 濃度分布 (FP)

Fig. 8 Contour Map for TCE Concentration (surveyed, using FP) 
対し有限要素法によるモデル化を行い、流れ場の再 現を試みた。現況再現においては、実測濃度分布結 果が比較的良好に整理されている1988年の調查結果 （表一 1 中の No. 3 の図-2）を対象としている。 モデル化では以下の仮定を設けた。

(1)単一不圧帯水層から成り、定常的なダルシー流 れで、平面二次元的に解析が可能である。

(2)領域内に扔けるZ川上流部、T川、B 川からは 地下水かん養が、 Z川下流部で流出があり、か ん養量と流出量のオーダーは等しい。

(3)領域内で地下水流れに影響を与えると考えられ る、8地点での地下水揚水量を考慮し、それら 揚水地点近傍に㧍ける地下水の鉛直方向流動は 無視できるとした。

(4)土地利用形態に基づいて降雨浸透、蒸発散を計 算する。

(5)透水係数の実測值抢よび地質資料を参考に、領 域内における透水係数分布を 2 つのブロックに 分ける。

(2)基礎指揮と計算条件 流れ場の基脴方程式を以下に示す。

(1) ダルシーの式 $\mathrm{q}=-\mathrm{K} \cdot \operatorname{grad} \mathrm{h}$

(2) 連続の式 $\frac{\partial}{\partial x}\left(K \frac{\partial h}{\partial x}\right)+\frac{\partial}{\partial y}\left(K \frac{\partial h}{\partial y}\right)=0$

ここに、 $\mathrm{h}$ : 地下水頭 $(\mathrm{L}) 、 \mathrm{~K}:$ 透水係数 $\left[\mathrm{LT}^{-1}\right]$ である。

これらの仮定を踏まえ、対象領域の設定を行った。 設定にあたっては現状の污染の拡がりの程度、並び に地下水流動傾向を考慮した。また、地下水の流下 万向と予測される南西側では J川の一部を水位規定 の境界条件として取り込むようにした。透水係数は 既往の工事記録をもとにブロックごとに設定した。 また河川かん養量は実測值がないので既往の検討手 法より算出した（例えば土木工学ハンドブック第 8 編参照)。河川流出量についても実測值がないため、 仮定(2)をもとに設定した。降雨、蒸発散量は領域内 の市街化状況、排水整備状況、植生等を踏まえ設定 した。揚水量については当市の地下水利用実態調査 記録をもとに、浅層からの揚水量を整理した。ここ で地下水流れ場解析コードとしては汎用プログラム UNISSF（地下水変動解析プログラム、 CRC (株))
を用いた（節点数 $=311$ 、要素数 $=275$ 、四角形要素 使用、メッシュ間隔 $=100 \mathrm{~m}$ )。

\section{2.濃度場のモデル化}

(1)基礎式と計算条件

濃度場の計算は、次の平面二次元の移流拡散方程 式(1)を有限要素法で定式化することにより行った。

$$
\begin{aligned}
& (\theta+\rho K d) \frac{\partial c}{\partial t}-\frac{\partial}{\partial x} \cdot\left(\theta \operatorname{Dxx} \frac{\partial c}{\partial x}+\right. \\
& \left.\theta \operatorname{Dxy} \frac{\partial c}{\partial y}\right)+V x \frac{\partial c}{\partial x}-\frac{\partial}{\partial y}\left(\theta \operatorname{Dyx} \frac{\partial c}{\partial x}\right. \\
& \left.+\theta \operatorname{Dyy} \frac{\partial c}{\partial y}\right)+V y \frac{\partial c}{\partial y}=0
\end{aligned}
$$

ここに、c：溶質物質の濃度 $\left[\mathrm{ML}^{-3}\right] 、 \mathrm{Kd}$ ：分配係 数 (吸着率) $\left[\mathrm{M}^{-1} \mathrm{~L}^{3}\right) 、 \theta$ : 体積含水率、 $\rho$ : 単位 体積あたりの土壤重量 $\left[\mathrm{ML}^{-3}\right] 、 \mathrm{v}_{\mathrm{x}}, \mathrm{v}_{\mathrm{y}}$ : ダルシー 流速 $\left[\mathrm{LT}^{-1}\right] 、$ Dxx, Dxy, Dyx, Dyy : 分散係数 $\left[\mathrm{L}^{2} \mathrm{~T}\right.$ -1]である。

ここで定式化はLOD-CFEM（Locally One Dimensional-Collocation Finite Element Method: 井上ら、 1984）を用いた。本手法は空間多次元の非定常偏微 分方程式を精度よく效率的に数值計算するのに優れ ている。具体的には、まず二次元移流拡散方程式を LOD 法により以下のように一次元に分割する。

$$
\begin{gathered}
x \text { 方向 : }(\theta+\rho \mathrm{Kd}) \frac{\partial c}{\partial t}=\frac{\partial}{\partial x}\left(\theta \operatorname{Dxx} \frac{\partial c}{\partial x}\right) \\
+\frac{\partial}{\partial x}\left(\theta \operatorname{Dxy} \frac{\partial c}{\partial y}\right)^{*}-V x \frac{\partial c}{\partial x}
\end{gathered}
$$

$\mathrm{y}$ 方向 : $(\theta+\rho \mathrm{Kd}) \frac{\partial \mathrm{c}}{\partial \mathrm{t}}=\frac{\partial}{\partial \mathrm{y}}\left(\theta \operatorname{Dyy} \frac{\partial \mathrm{c}}{\partial \mathrm{y}}\right)$

$$
+\frac{\partial}{\partial y}\left(\theta \operatorname{Dyx} \frac{\partial c}{\partial x}\right)^{*}-V y \frac{\partial c}{\partial y}
$$

$$
\text { ここに式中に*印の項 } \frac{\partial}{\partial \mathrm{x}}\left(\theta \mathrm{Dxy} \frac{\partial \mathrm{c}}{\partial \mathrm{y}}\right) \text { 、 }
$$

$\frac{\partial}{\partial y}\left(\theta\right.$ Dyx $\left.\frac{\partial c}{\partial x}\right)$ は外力項として扱う。

次に分割後、それらを CFEM で離散化する手法で 
ある。ここで、濃度場における移流（地下水流れ） 項は、前節の地下水流れ場の計算結果をもとに、節 点毎の成分を算出し直し、計算された。

(2)数值モデルの設定

数值モデルとしては、濃度、地下水実測コンター より表ー 3 に示す計算ケースを設定し、污染プ リュームの拡散傾向を検討すると共に、領域内主要 河川 Z 川への污染物質流出量の定量評価を試みた。 ここで、污染源は現地調查結果を踏まえて複数連続 源と仮定した。また汗染物質の流出筒所としては、 領域内揚水箇所 $\left(484.5 \mathrm{~m}^{3} /\right.$ day : 逆推定後に抢ける 浅層からの地下水揚水総量)、 $Z$ 川河川流出区間 $\left(700 \mathrm{~m}, 7280 \mathrm{~m}^{3} / \mathrm{day}\right)$ が考えられるが、ここでは 水収支項目のオーダー比較から Z 川下流部流出区間 を流出対象とし、内部境界条件処理を行った。また 表 -3 中備考闌の記号 Pe, F, G は各々ペクレ数、ク ラーン数、拡散数と呼ばれ、次式により定義される (平岡ら、1982年)。

$$
\begin{aligned}
& \mathrm{Pe}=\mathrm{U} \cdot \Delta \mathrm{L} / \mathrm{D} \\
& \mathrm{F}=\mathrm{U} \cdot \Delta \mathrm{t} / \Delta \mathrm{L} \\
& \mathrm{G}=\mathrm{D} \cdot \Delta \mathrm{t} / \Delta_{\mathrm{L}}{ }^{2}
\end{aligned}
$$

ここにU：代表流速、 $\Delta \mathrm{L} ：$ 代表長さ（メッシュ間 隔 $=100 \mathrm{~m}$ )、 $\Delta \mathrm{t}$ : 計算時間間隔、 $\mathrm{D}$ : 拡散係数であ る。ここでPe数等の無次元数は、対象領域内で平 均的に決めている。予測計算においては、数值モデ ルの安定性を保持するため、以下の安定条件下で L、 $\Delta \mathrm{t}$ の設定を行った。

\section{表- 3 濃度場計算ケース}

\begin{tabular}{|c|c|c|c|c|}
\hline case & 污染源数 & 分散能 & 時間ピッチ & 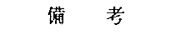 \\
\hline 1 & $1(\mathrm{~A})$ & \multirow{3}{*}{$\begin{array}{l}a_{\mathrm{L}}=100 \mathrm{~m} \\
a_{\mathrm{T}}=20 \mathrm{~m}\end{array}$} & \multirow{3}{*}{$\Delta \mathrm{t}=60 \mathrm{~B}$} & \multirow{3}{*}{$\begin{array}{l}\mathrm{Pe}=1.0, \mathrm{~F}=0.06 \\
\mathrm{G}=0.06 \\
\mathrm{D}=10 \mathrm{~m}^{2} / \mathrm{B}\end{array}$} \\
\hline 2 & $1(B)$ & & & \\
\hline 3 & $2(A, B)$ & & & \\
\hline 4 & $1(\mathrm{~A})$ & \multirow{3}{*}{$\begin{array}{l}a_{\mathrm{L}}=50 \mathrm{~m} \\
a_{\mathrm{T}}=10 \mathrm{~m}\end{array}$} & \multirow[t]{3}{*}{$\Delta \mathrm{t}=60$ 日 } & \multirow{3}{*}{$\begin{array}{l}\mathrm{Pe}=2.0, \mathrm{~F}=0.06 \\
\mathrm{G}=0.03 \\
\mathrm{D}=5 \mathrm{~m}^{2} / \mathrm{B}\end{array}$} \\
\hline 5 & $1(B)$ & & & \\
\hline 6 & $2(A, B)$ & & & \\
\hline
\end{tabular}

Table 3 Cinditions for the Numerical Simulation of Concentration

$\mathrm{Pe}=\mathrm{U} \cdot \Delta_{\mathrm{L}} / \mathrm{D}, \mathrm{F}=\mathrm{U} \cdot \Delta_{\mathrm{t}} / \Delta_{\mathrm{L}}, \mathrm{G}=\mathrm{D} \cdot \Delta_{\mathrm{t}} / \Delta_{\mathrm{L}}{ }^{2}$

で、ここに $\Delta \mathrm{L}=100 \mathrm{~m}, \Delta \mathrm{t}=60 \mathrm{日}, \mathrm{U}=0.1 \mathrm{~m} /$ 日である。 $\operatorname{Dxx}=\left(\alpha_{\mathrm{L}} \cdot \mathrm{Uxx}^{2}+\alpha_{\mathrm{T}} \cdot \mathrm{Uyy}^{2}\right) / \mathrm{U}+\mathrm{Dd}$

$D y y=\left(a_{\mathrm{l}} \cdot U \mathrm{yy}^{2}+\alpha_{\mathrm{T}} \cdot U \mathrm{xx}^{2}\right) / U+D d$

Dxy $=D_{y x}=\left(\alpha_{1}-\alpha_{T}\right) \cdot \mathrm{Uxx}_{\mathrm{xx}} \cdot \mathrm{Uyy} / \mathrm{U}$

$$
\begin{gathered}
0<\mathrm{Pe}<10.0 \\
0<\mathrm{F}<1.0 \\
0.01<\mathrm{G}<1.0
\end{gathered}
$$

また拡散係数テンソルは次式より与えられるものと する(Bear、1972)。

$$
\begin{aligned}
& \operatorname{Dxx}=\left(\alpha_{\mathrm{L}} \cdot \mathrm{Uxx}^{2}+\alpha_{\mathrm{T}} \cdot \mathrm{Uyy}^{2}\right) / \mathrm{U}+\mathrm{Dd} \\
& \operatorname{Dyy}=\left(\alpha_{\mathrm{L}} \cdot \mathrm{Uyy}^{2}+\alpha_{\mathrm{T}} \cdot \mathrm{Uxx}^{2}\right) / \mathrm{U}+\mathrm{Dd} \\
& \operatorname{Dxy}=\mathrm{Dyx}=\left(\alpha_{\mathrm{L}}-\alpha_{\mathrm{T}}\right) \cdot \mathrm{Uxx} \cdot \mathrm{Uyy} / \mathrm{U}
\end{aligned}
$$

ここに $\mathrm{Uxx} 、 \mathrm{Uyy}$ ：間隙流速 $\mathrm{U}$ の各々 $\mathrm{x}, \mathrm{y}$ 成分、 $\alpha_{\mathrm{I}}$ : 流れの力向の分散能、 $\alpha_{\mathrm{T}}$ : 流れに法線力向の 分散能、Dd：間隙水中の溶質の分子拡散係数であ る。

また内部境界条件のモデル化は、仮想問題（矩形領 域の二次元一様流れにおける移流拡散問題）を用い て検証を行った。詳紐は省くが、物質流出のモデル 化を行った場合とそうでない場合の濃度場出力結果 での解の安定性等をチェックし、モデル化の妥当性 䚵価を試みた。

\section{5. 解析結果}

\section{1.地下水流机場の解析結果}

図ー9は逆推定を行う前の状態で地下水流れ場を

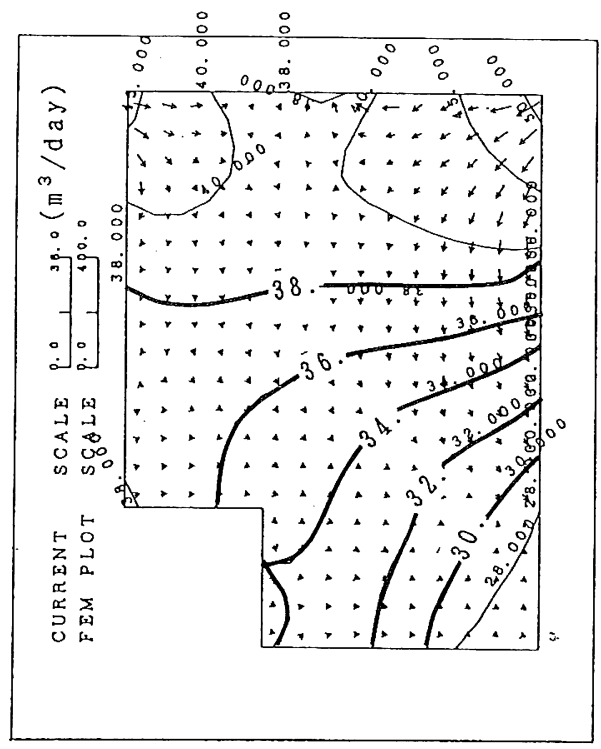

図-9 地下水位計算出力

Fig. 9 Contour Map for Groundwater Level (computed) 
再現したものであるが、同図より実測地下水位分布 との問に局所的な差異があるものの、領域北東、北 西から南東に向かう地下水流れが再現されており全 体的には良好な一致が認められる。

次に、透水係数 $(\mathrm{K} 1=6.3 \mathrm{~m} / \mathrm{day}, \mathrm{K} 2=2.4 \mathrm{~m} / \mathrm{day})$ 、 河川流出量 $\mathrm{R} \quad\left(\mathrm{R} 1=800.0 \mathrm{~m}^{3} / \mathrm{day}, \mathrm{R} 2=\right.$ $100.0 \mathrm{~m}^{3} / \mathrm{day}$ )、領域内揚水量 $\mathrm{P}$ に関して感度解析 を踏まえたうえで、その絬果をもとに逆解析を行う

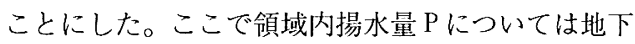
水利用実態調查表において揚水深度、揚水規模が比 較的大である図-4のNo. 5 、No. 6 の 2 揚水地点 $\left(\mathrm{P} 5=300, \mathrm{P} 6=132 \mathrm{~m}^{3} / \mathrm{day}\right)$ を対象としている。 まず感度解析として、K、R、Pの各一次設定值に 対し、各々のパラメーターの值を個別に変化させた 場合に打ける各々の流れ場を計算し、領域内に存在 する 8 観測地点（図一 4 参照）の地下水位観测値と 計算值との残差平方和 RSQ を算出した。この RSQ の変化、椪びに流れ場の出力結果を比較することに より、河川流出量 $\mathrm{R} か ゙ 、$ 揚水量 $\mathrm{P}$ および透水係数 $\mathrm{K}$ よりコンター形状の変化に与える影響が大きいこと
が認められた。

これらのことを踏まえて $\mathrm{K} 、 \mathrm{R} 、 \mathrm{P}$ の逆推定を行っ た。推定は非線形最小二乗法に基ついている。また 推定の良否判定に用いる評価基準は、領域内に存在 する 8 観測地点の地下水位観測值を採用した。推定 手順としてまずK、R、Pの各々に対し、単独に逆 推定を試み、次に各变数を組み合わせたものに対し、 各々逆推定を試みた。図ー10は、逆推定に伴う RSQの変化を整理したものである。単独推定の場 合、Rに関して比較的大きいRSQの低減があるこ とがわかる。また全体的に見て、逆推定のパラメー 夕数を增やすにつれ、RSQが低減していくことが 認められる。図一11は、逆推定に伴う流れ場の水収 支残余 RWBの変化を整理したものである。残差平 方和 RSQのように、推定パラメーター数の増大に つれ、RWBが全体的に低減するような傾向は認め られない。これは、当検討で用いた逆推定が、地下 水位の制約条件のみに関して設定されていることに よると考えられる。したがって水収支を重視した地 下水流れ場の逆推定を行う場合、地下水位だけでな

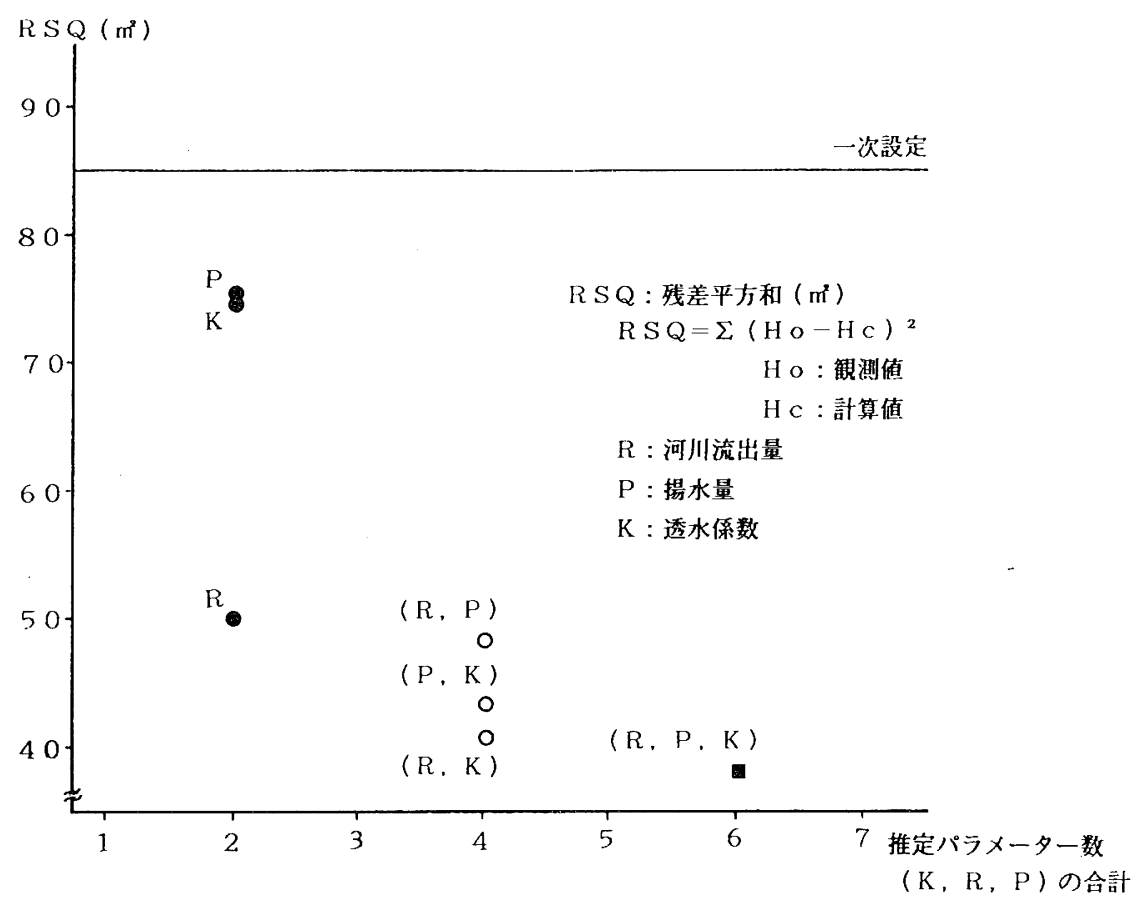

図-10 逆推定に伴う残差平方和 RSQ

Fig.10 Relation between the RSQ and the Number of unkown Parameters 


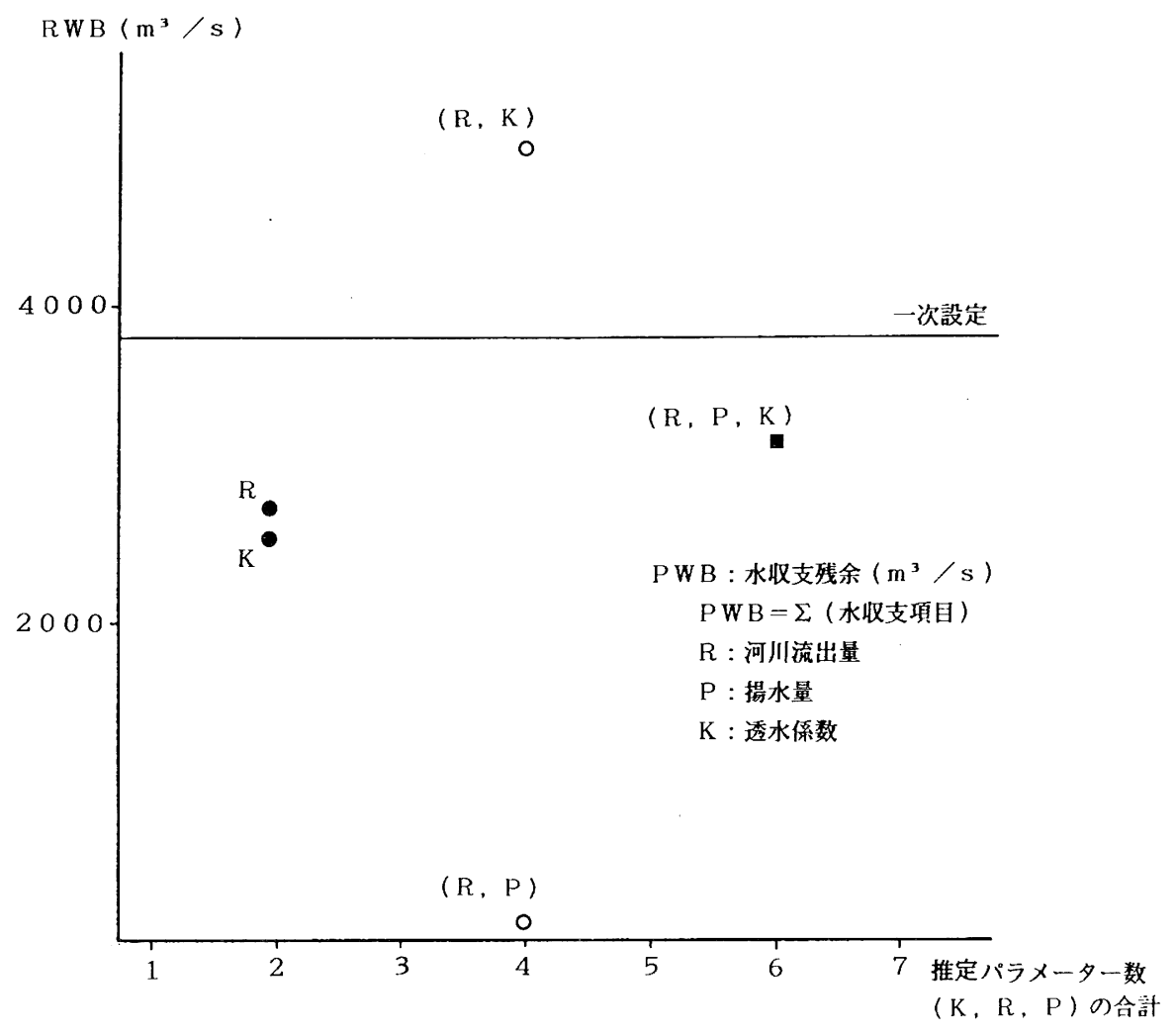

図-11 逆推定に伴う領域内水収支

Fig.11 Relation between the RWB and the Number of unkown Parameters

く、地下水位と水収支を同時に満足する制約条件を 設定することが必要であることがわかる。

当検討においては、流れ場の水収支が検討範讲内 で最も改良された（R, P）の逆推定結果をもとに、 濃度場の計算に移行した。図ー12は、逆推分に伴う 計算地下水位の変化を示したものである。

全ケースともに逆推定を行うにつれ、その残差平 方和 $\Sigma\left(\mathrm{Ho}_{\mathrm{o}}-\mathrm{Hc}\right)^{2}$ は次第に減少してゆき、今回の結 果ではその值が $8.7 \mathrm{E}+01$ から $4.9 \mathrm{E}+01 \mathrm{~m}^{2}$ と減少す る。ここで、Ho：地下水位観測值、 $\mathrm{Hc}$ ：地下水位 計算值である。浅層の平均带水層厚が約 $30 \mathrm{~m}$ である ことを考慮すれば、 $4.9 \mathrm{E}+01 \mathrm{~m}^{2}$ の評仙誤差は評洒 地点当り約 $1 \mathrm{~m}$ で、これは評価基準の水位の約 $3 \%$ $\left(\left(\Sigma(\mathrm{Ho}-\mathrm{Hc})^{2}\right)^{0.5} / 8 / \mathrm{Ho}\right)$ に相当し、解析範囲内 では良好な結果と言える。

\section{2.濃度場の解析結果}

図一13〜図-15は case 3 におけるそれぞれ 3 年

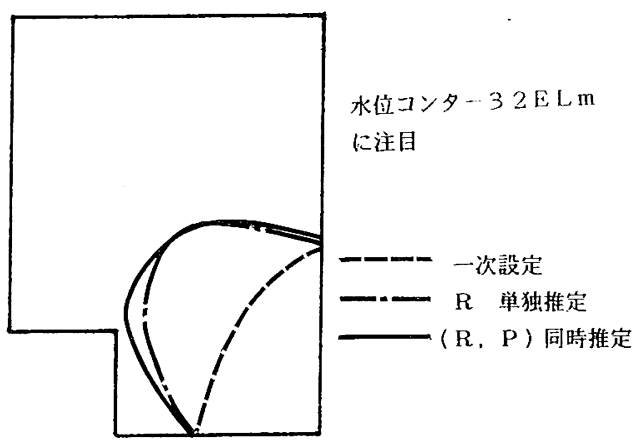

図-12 逆推定に伴うコンター形状变化

Fig.12 Comparsison of Groundwater Level with Inverse Estimation and Others

後、 9 年後、15年後の濃度コンターを出力したもの である。地下水流れ場のベクトル方向に沿って污染 プリュームが移動し、ある期間を経過後、Z川への 流出部付近で流出に伴う濃度コンターの低下が認め 


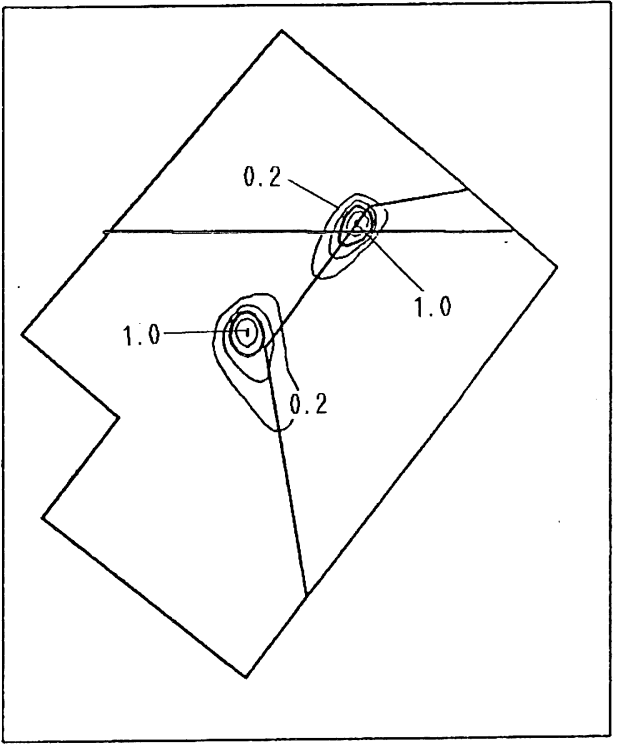

図-13 case 3 ( 3 年後)

Fig.13 Results of Simulation Case 3 ( $T=3$ year)

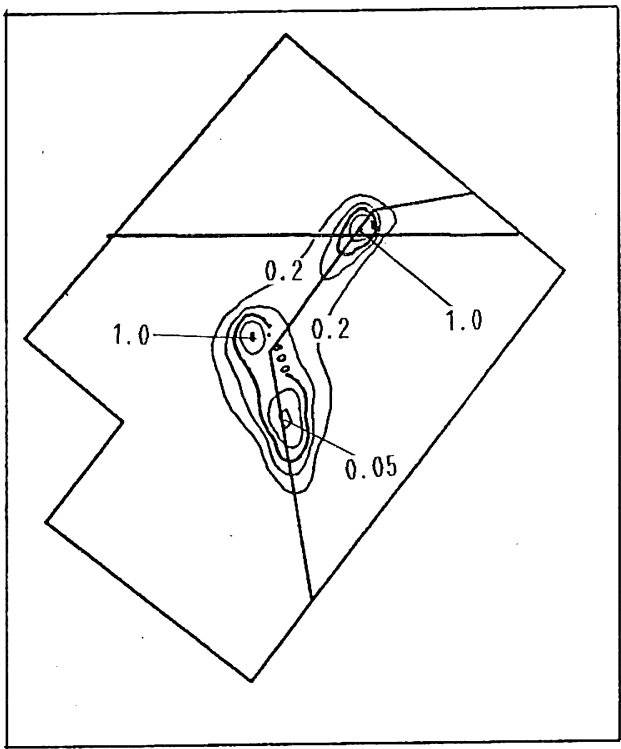

図-14 case 3 ( 9 年後)

Fig.14 Results of Simulation Case $3 \quad(T=9$ year)

られる。この傾向は全ケースにおいて確認された。 また図ー16は case 6 における15年後の計算結果を 出力したものである。同ケースにおいても拡散のス ピードは早いが、同様な污染パターンが認められる。

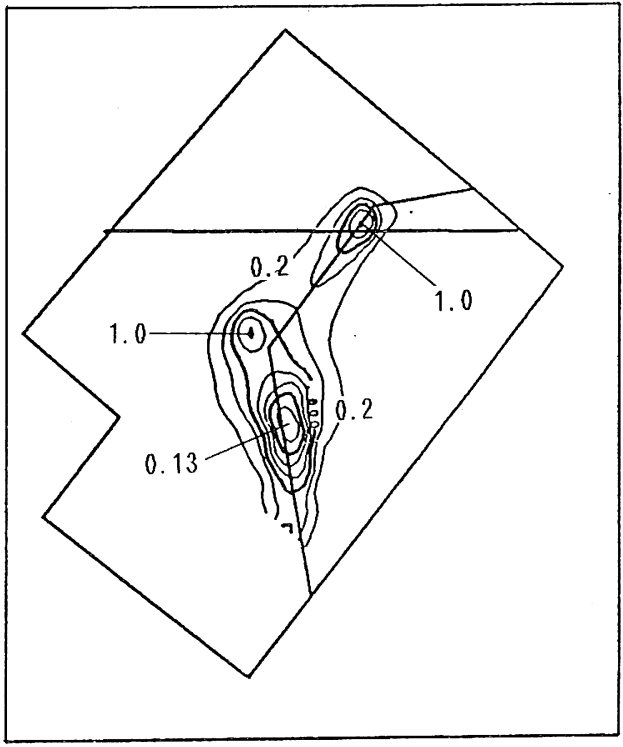

図-15 case 3 (15年後)

Fig.15 Results of Simulation Case 3 ( $\mathrm{T}=15 \mathrm{year}$ )

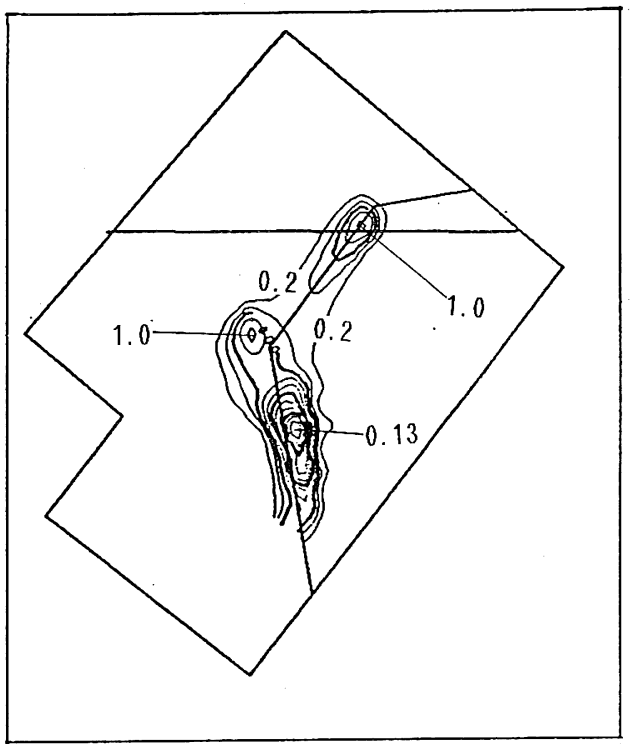

図-16 case 6 (15年後)

Fig.16 Results of Simulation Case $6 \quad(T=15 y e a r)$

図ー17は各ケースごとの領域内主要河川 $Z$ 川への 污染物質流出率 RR を整理したもので、RRは次式 より算出した。 


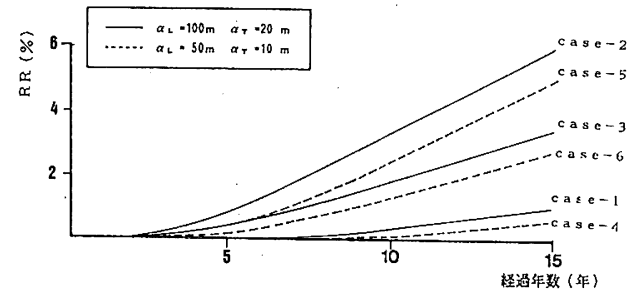

図-17 河川流出率

Fig.17 The Time Variation of Rate of mass releasing into the Rever from Groundwater

$$
\mathrm{RR}(\%)=100 \cdot \mathrm{Ha}_{\text {out }} / \mathrm{Ha}_{\text {in }}
$$

ここに $\mathrm{Ha}_{\text {out }}$ : 累積河川流出総量で、地下水の河川 流出区間における污染物質流出総量、 $\mathrm{Ha}_{\mathrm{in}}$ : 累積污 染物質投入量で、領域内への污染源からの污染物質 投入量である。ここで計算期間は 15 年としている。 図ー17より、ある期間を経過後、経時的に、また分 散能（拡散係数）が増加するにつれRR が増加する ことが諗められる。case 3、6でみれば、15年経過 時においては RR が各々 $3.4 、 2.8 \%$ となり、漏出後、 同時点において污染物質の大部分は領域内带水層中 に残存すると言える。

\section{6. おわりに}

本研究では、J市X区の污染事例に対し現地調査 し、それらの結果をもとに地下水流れ場、濃度場に ついて数理モデルを構築し、河川を考虑した污染機 構の解明、影響予測について検討した。本研究より 得られた知見を以下に述べる。

(1)対象領域における現地調査結果を踏まえて、 地下水流れ場を把握するための地下水位コン ターを作成した。その時、領域内における降雨、 揚水、河川流出などの各水収支項目を整理す ることにより、流動特性の概略が把握できた。 濃度場については、測定值から TCE, PCEの 濃度コンターを作成し、使用実態等の現地調 査結果と併せた污染源位㯰の絞り込みが行え た。
(2)現地調査結果、既往の検討資料をもとに地下 水流れ場の数理モデルを構筑し流れ場を再現 すると同時に、透水係数、河川流出量、領域 内揚水量に対し感度解析、逆解析を行った。 感度解析結果としては検討範囲内で河川流出 量が領域内揚水量及び透水係数より流れ場の コンター形状の変化に与える影響が大きいこ とが認められた。また逆解析により、領域全 体に拐ける水収支のバランスが改良され、モ デルの信頼性を合理的に向上させることが出 来た。

さらに、水収支を向上させるためには、地 下水位と同時に水収支に関する制約条件を、 逆推定に設定する必要性が示せた。

(3)LOD-CFEMにより濃度場の数理モデルを構築 し、現況污染状況の再現を試み、同手法の有 効性を確認することが出来た。また同モデル により、地下水から領域内主要河川 $Z$ 川への 污染物質の流出について予測を試みた結果、 15年経過時点においては、污染物質の大部分 は領域帯水層中に残存することが予测された。

最後に、当污染事例に関し御討議頂いた大阪大学 村岡浩爾博士、国立公害研究所中杉修身博士、筑波 大学田瀬則雄博士、並びにUNISSF 利用で御援助頂 いた CRC(株)田中豊氏、今井紀和氏に対し深甚の 謝意を表します。

\section{参 考 文 献}

金子良（1973）：農業水文学、共立出版 土木学会編（1979）：土木工学ハンドブック、技報堂 平岡正勝、古市徹、田中宏明（1982）：移流拡散方程式の 数偭解の安定性解析、土木学会論文報告集、No.319, pp77 85

井上賴輝、古市徹、片川秀樹（1984）：LOD-CFEM を適用 した飽和一不飽和地下水層における物質移動シミュレー ション. 京都大学環境衛生工学研究会シンポジウム講演 論文集， 6，pp248～255

CRC(株)：UNISSF-1, UNISSF-2の利用者マニュアル

Bear, J. (1972) Dynamics of Fluids in Porous Media, Amer ican Elsevier.

（受付：1989年 9 月 2 日、受理：1990年 4 月 2 日) 